\title{
Ocena możliwości wykorzystania desorpcji termicznej do wyznaczania charakteru nasyceń w profilu odwiertu
}

\section{Assessment of thermal desorption method application for determination of the saturation characteristics along borehole}

\author{
Irena Matyasik, Marek Zapała, Maria Kierat, Małgorzata Kania, Wojciech Bieleń, Karol Spunda \\ Instytut Nafty i Gazu - Państwowy Instytut Badawczy
}

\begin{abstract}
STRESZCZENIE: Celem niniejszej pracy jest przedstawienie szybkiej metody oceny typu wolnych węglowodorów, występujących w profilu otworu, wykorzystującej jako narzędzie pirolizę połączoną z chromatografią gazową (Py-GC). Metoda ta, jako alternatywa dla dotychczas stosowanych - pirolizy Rock-Eval i ekstrakcji rozpuszczalnikowej, mogłaby służyć do typowania poziomów do bardziej szczegółowych badań. W tym celu wykonano badania porównawcze rdzeni pochodzących ze strefy akumulacji ropy naftowej w utworach dolomitu głównego na Niżu Polskim. Wyniki eksperymentów Py-GC prowadzonych w $350^{\circ} \mathrm{C}$ z detekcją desorbowanych związków na detektorze płomieniowo-jonizacyjnym (Py-GC/FID) dowiodły pozytywnej korelacji z ilością wolnych węglowodorów ( $\mathrm{S}_{1}$ ) uwalnianych $\mathrm{w} 300^{\circ} \mathrm{C}$ podczas pirolizy Rock-Eval oraz zawartością ekstrahowalnej substancji organicznej (ESO). Metoda Py-GC/FID ma jednak tę przewagę nad pozostałymi dwiema metodami, że otrzymany chromatogram pokazuje dystrybucję desorbowanych węglowodorów i umożliwia obliczenie niektórych wskaźników geochemicznych, co pozwala na wstępną charakterystykę akumulacji. Ocenę przydatności metody w aspekcie charakterystyki uwalnianych produktów przeprowadzono, wykonując dla kilku badanych rdzeni analizy chromatograficzne GC-FID frakcji nasyconej ekstraktu bitumicznego i obliczając na ich podstawie wskaźniki geochemiczne. Wyniki porównania wykazały generalnie podobieństwo dystrybucji węglowodorów, a dla niektórych próbek również zgodność obliczonych wskaźników. Na tej podstawie należy uznać, że dystrybucja produktów desorpcji Py-GC/FID skał w $350^{\circ} \mathrm{C}$ pozwala na uzyskanie części informacji dostarczanych przez analizę chromatograficzną GC-FID frakcji nasyconej ekstraktu bitumicznego bez konieczności wstępnej preparatyki chemicznej materiału rdzeniowego, co znacznie skraca czas i obniża koszty analizy. Dystrybucja desorbowanych węglowodorów w korelacji z wynikami pirolizy Rock-Eval może stanowić narzędzie typowania poziomów do szczegółowej charakterystyki geochemicznej. Procedura poszerza zakres badań geochemicznych o kolejną metodę wnoszącą wkład do rozpoznania basenów naftowych.
\end{abstract}

Słowa kluczowe: skała macierzysta, desorpcja węglowodorów, Py-GC - piroliza połączona/sprzężona z chromatografią gazową, dolomit główny.

\begin{abstract}
The purpose of this work was to present a quick method for assessing the type of free hydrocarbons occurring in the borehole profile, using pyrolysis combined with gas chromatography (Py-GC) as a tool. This method, as an alternative for the previously used Rock Eval pyrolysis and solvent extraction - could be used to select levels for more detailed research. For this purpose, comparative tests were carried out of cores originating from the oil accumulation zone in the Main Dolomite formations in the Polish Lowlands. The results of Py-GC experiments carried out at $350^{\circ} \mathrm{C}$ with the detection of desorbed compounds on the flame ionization detector (Py-GC/FID) showed a positive correlation with the amount of free hydrocarbons (S1) released at $300^{\circ} \mathrm{C}$ during Rock-Eval pyrolysis and the content of extractable organic substance (ESO). However, the Py-GC/FID method has the advantage over the other two methods in that the resulting chromatogram shows the distribution of desorbed hydrocarbons and makes it possible to calculate some geochemical indicators, allowing the preliminary characterization of accumulation. The assessment of the method's usefulness in terms of the characteristics of released products was carried out by performing GC-FID chromatographic analyses of the saturated fraction of bituminous extract for several tested cores and calculating the geochemical indices on their basis. The results of the comparison generally demonstrated a similarity of hydrocarbon distribution, and for some samples also compliance with the calculated indices. On this basis, it should be considered that the distribution of Py-GC/FID desorption products of rocks at $350^{\circ} \mathrm{C}$ allows obtaining part of the information provided by GC-FID chromatographic analysis of the saturated fraction of the bituminous extract without the need for chemical pre-treatment of the core material, which significantly reduces the time and costs of analysis. The distribution of desorbed hydrocarbons in correlation with the results of Rock Eval pyrolysis can be a tool for selecting levels for detailed geochemical recognition. The procedure extends the scope of geochemical research with another method contributing to the recognition of oil basins.
\end{abstract}

Key words: source rock, desorption of hydrocarbons, Py-GC - pyrolysis coupled with gas chromatography, Main Dolomite.

Autor do korespondencji: M. Kierat, e-mail: maria.kierat@inig.pl

Artykuł nadesłano do Redakcji 9.07.2019 r. Artykuł zatwierdzono do druku 22.11.2019 r. 


\section{Wprowadzenie}

Prace prowadzone w Laboratorium Geochemii Nafty i Gazu Instytutu Nafty i Gazu - Państwowego Instytutu Badawczego nad wykorzystaniem metody pirolizy połączonej z chromatografią gazową, zwanej też pirolityczną chromatografią gazową (Py-GC), do oceny składu molekularnego węglowodorów generowanych z różnego typu skał macierzystych wykazały przydatność tej metody analitycznej do przeprowadzenia bezpośredniej desorpcji wolnych węglowodorów z próbek skalnych (rdzeniowych lub okruchowych), dając przy tym możliwość oceny jakościowej uwalnianych produktów (Matyasik et al., 2017). Badania wykonywano na surowych próbkach skał. Przygotowanie próbki do analizy ograniczało się jedynie do rozdrobnienia skały do odpowiedniej granulacji. Tak prosta i szybka preparatyka wstępna próbek skłoniła zespół do podjęcia prac nad zaadaptowaniem metody Py-GC do desorpcji węglowodorów z gleb, co można wykorzystać do oceny zanieczyszczeń substancjami ropopochodnymi. Opracowano metodę półilościową pozwalającą na śledzenie propagacji zanieczyszczeń bez możliwości oceny ilościowej w zakresie stężeń niższych od 730 mg/kg suchej masy gleby (Matyasik et al., 2018).

Obecnie podstawą typowania próbek do dalszych badan geochemicznych są wyniki pirolizy Rock-Eval, które dostarczają informacji o zasobności skał w materię organiczną, jej typie genetycznym oraz dojrzałości termicznej. Na podstawie wyników pirolizy Rock-Eval nie można jednak scharakteryzować typu występujących związków. Takie możliwości oferuje metoda pirolitycznej chromatografii gazowej (Py-GC). Zastosowanie metody Py-GC w zakresie $300-400^{\circ} \mathrm{C}$ prowadzi do desorpcji wolnych węglowodorów, zaś uzyskany chromatogram pozwala na wstępną charakterystykę akumulacji pod kątem zawartości i dystrybucji związków węglowodorowych, które mogą być desorbowane z próbek skał. Uznano więc, że ta szybka metoda będzie przydatna w pracach nad charakterystyką nasyceń w profilu otworu, a w korelacji z wynikami pirolizy Rock-Eval będzie stanowić dobre narzędzie do typowania poziomów do dalszego rozpoznania geochemicznego.

\section{Przegląd możliwości Py-GC}

Pirolityczna chromatografia gazowa Py-GC rozwinęła się jako skuteczna metoda analityczna do badań polimerów naturalnych (biopolimerów) i sztucznych. Piroliza powoduje rozpad makromolekuł na mniejsze cząsteczki przy użyciu energii termicznej. Połączenie jej z chromatografią gazową lub chromatografią gazową sprzężoną ze spektrometrią mas stanowi szybką, wydajną i wygodną metodę charakteryzowania polimerów poprzez analizę produktów ich rozkładu. Istotą metody Py-GC jest połączenie pirolizera z chromatografem gazowym tak, aby produkty pirolizy trafiały (bezpośrednio lub przez interfejs) na kolumnę chromatografu gazowego, gdzie następuje ich rozdział. Zgodnie z tą naczelną zasadą, zależnie od celu badań oraz postępu technicznego, są projektowane i udoskonalane różne zestawy analityczne, najczęściej różniące się rodzajem pirolizera i sposobem detekcji (Sobeih et al., 2008). W praktyce laboratoryjnej wykorzystywane są trzy typy konwencjonalnych pirolizerów, różniące się sposobem ogrzewania próbki. Wszystkie one wymagają połączenia z chromatografem gazowym przez interfejs, przez co zostaje wydłużona droga produktów pirolizy do kolumny chromatograficznej, w dodatku muszą one przechodzić przez strefę o niższej temperaturze, co może prowadzić do kondensacji związków wysokocząsteczkowych, a co za tym idzie - do zmniejszenia intensywności odpowiadających im pików na chromatogramie.

Aby wyeliminować niekorzystny wpływ interfejsu, opracowano zestaw analityczny zwany non-discriminating $P y-G C$ system lub in-column pyrolysis (Górecki i Poerschmann, 2001), który ogranicza straty próbki i zapobiega utracie związków wysokocząsteczkowych, gdyż piroliza zachodzi w kapilarze, bezpośrednio połączonej z portem nastrzykowym i kolumną chromatografu. Autorzy przeprowadzili pirolizę polietylenu, uzyskując jako produkty alkany aż do $\mathrm{C}_{58}$, przy czym granica ta wynikała jedynie $z$ ograniczeń temperaturowych kolumny chromatograficznej. W kolejnych pracach twórcy metody potwierdzili zastosowanie non-discriminating Py-GC/MS do badań składu naturalnej materii organicznej (Parsi et al., 2007). Badania były prowadzone na wzorcowych preparatach chityny oraz dla materii organicznej wyizolowanej z trzeciorzędowych osadów piaszczystych

Związki opuszczające kolumnę po Py-GC mogą trafiać bezpośrednio do detektora płomieniowo-jonizacyjnego (FID) lub detektora emisji atomowej-AED, w które może być wyposażony chromatograf. Obecnie jednak większość badań metodą pirolitycznej chromatografii gazowej jest prowadzona z zastosowaniem detektora spektrometrii mas w trybie Py-GC/MS. Spektrometr masowy, zależnie od sposobu jonizacji, pozwala osiągnąć różny stopień defragmentacji molekuł. Szeroki przegląd zastosowań Py-GC/MS opisali Peacock i McEwen (2006). Spektrometria masowa ma tę przewagę nad detektorem FID (i wieloma innymi), że pozwala identyfikować szerokie spektrum związków chemicznych na podstawie liczb masowych $(\mathrm{m} / \mathrm{z})$ jonów defragmentacyjnych i opracowanych na ich podstawie bibliotek. Inne detektory zazwyczaj wymagają zastosowania wzorców, nie tylko do kalibracji, ale już na etapie identyfikacji składników. Jak wykazali jednak badacze niemieccy (Salinas et al., 2016), walidując metody Py-GC/MS i Py-GC/FID dla syntetycznych polimerów, detekcja płomieniowo-jonizacyjna (FID) jest właściwsza do celów ilościowych 
niż spektrometria masowa. Świadczyły o tym wartości wszystkich parametrów statystycznych takich jak: precyzja, zakres liniowości, dokładność, odtwarzalność, granica wykrywalności i granica oznaczalności.

Kolejne rozszerzenie metod detekcji to układ Py-GC/IRMS, z zastosowaniem detektora izotopowego spektrometru mas, który pozwala na bardzo precyzyjną analizę składu trwałych izotopów w związkach organicznych obecnych w pirolizacie po rozdziale GC/MS (Sessions, 2006; Janiga et al., 2018).

Próbka na Py-GC/MS często wymaga wstępnego przygotowania, polegającego najczęściej na przekształceniu nielotnego polarnego związku chemicznego w pokrewne bardziej lotne lub mniej trwałe termicznie pochodne. Proces ten, zwany derywatyzacją, jest od dawna stosowany w Py-GC/MS i szeroko udokumentowany (Challinor, 2001; Ikeya et al., 2006). Derywatyzacja rozszerza możliwości analizy pirolizatu poprzez poprawę zachowania analitu podczas rozdzielania w kolumnie, modyfikowanie ścieżki degradacji termicznej lub zwiększenie wykrywalności analitu.

Nowszą techniką mikroanalityczną jest Laser Py-GC, która dzięki użyciu mikroskopu i energii lasera jako źródła fragmentacji cząstek pozwala przeprowadzić kontrolowaną pirolizę w wybranym miejscu preparatu, dostarczając informacji o jednostkach strukturalnych makromolekuł in situ. Jest to istotne ze względu na heterogeniczną budowę wielu polimerów, w tym szczególnie naturalnych. Dzięki wysokiej energii lasera i bardzo krótkiemu czasowi promieniowania uwalnia się jednocześnie pełna gama produktów pirolizy i nie dochodzi do wtórnego krakingu (Meruva et al., 2004).

Metoda Py-GC jest rutynowo stosowana w badaniach polimerów syntetycznych do ich identyfikacji i rozróżnienia, jak również do ilościowego oznaczania zawartości monomerów w tworzywach sztucznych czy badania degradacji polimerów (Salinas et al., 2016). Bardzo szerokie zastosowanie Py-GC znalazła w badaniach zanieczyszczeń środowiska: zanieczyszczeń gleb (Pernot et al., 2013) czy osadów rzecznych i morskich, jak również w analizie toksycznych składników w pyle zawieszonym PM-10 i PM-2,5 (Gil-Moltó et al., 2009). Często jest $\mathrm{w}$ tych badaniach wykorzystywana metoda termodesorpcji Td-GC/MS (Yokoi et al., 2017). Metoda Py-GC jest szeroko stosowana do badań drewna, celulozy i żywic naturalnych, jak również w analizie żywności, w farmacji, w specjalistycznej diagnostyce medycznej, w archeologii, w kryminalistyce oraz w badaniach farb i lakierów (Milczarek et al., 2006).

Wykorzystanie analizy Py-GC interesuje nas najbardziej w aspekcie badań geochemii naftowej i surowców naturalnych. Badania prowadzone przez różnych badaczy (Bruan et al., 2001, Gonzalez-Vila et al., 2001) na próbkach kerogenu reprezentującego wszystkie typy genetyczne wykazały, że dekarboksylacja grup karboksylowych zhydrolizowanego kerogenu jest dominującym procesem podczas pirolizy, co wskazuje, że większość związków posiadających grupy funkcyjne jest połączona ze strukturą makrocząsteczek przez wiązania estrowe lub eterowe.

Metody pirolityczne w systemie otwartym i zamkniętym zostały wykorzystane do badań możliwości generacyjnych australijskiego basenu Gippsland Basin, obejmującego osady od górnej kredy do paleogenu (Abbassi et al., 2016).

Chińscy badacze zastosowali technikę Py-GC do desorpcji i analizy węglowodorów gazowych uwalnianych z węgla oraz z mułowcowych skał macierzystych, reprezentujących I i II typ kerogenu (Hu et al., 2017). W pracy analizowano również gazy ziemne generowane w złożach węgla oraz gazy związane z ropą naftową. Autorzy skupili się na izomerach oktanu, które ze względu na niską zawartość $\mathrm{C}_{8} \mathrm{~W}$ gazie ziemnym nie stanowiły dotychczas obiektu zainteresowania badaczy. Wykazano, że gaz pochodzący z węgla charakteryzuje się wysoką zawartością cykloalkanów (powyżej 40\%), podczas gdy w gazie związanym ze złożami ropy naftowej występuje mniejsza ilość izomerów cyklicznych, są one natomiast bogatsze w izoalkany. Na tej podstawie wyznaczono wskaźnik, który może być zastosowany do określenia źródła generowania gazu ziemnego. Zaobserwowano, że w gazach generowanych z węgla stosunek 2-metyloheptanu do 1-cis 3-dimetylocykloheksanu jest mniejszy od 0,5 , podczas gdy w gazach związanych ze złożami ropy naftowej przekracza on wartość 0,5 .

\section{Weryfikacja zakresu informacji i możliwości interpretacyjnych uzyskanych metodą desorpcji Py-GC na podstawie wyników archiwalnych (2016-2017)}

Jak wykazały wcześniejsze badania prowadzone w Zakładzie Geologii i Geochemii INiG - PIB (Matyasik et al., 2017), w $300^{\circ} \mathrm{C}$ mamy do czynienia jedynie z desorpcją wolnych węglowodorów. Porównanie składu produktów Py-GC/FID potwierdza, że w przedziale temperatur $300-400^{\circ} \mathrm{C}$ zachodzi pierwsza faza rozkładu kerogenu, aczkolwiek główna faza tego procesu przypada na przedział temperatur $400-650^{\circ} \mathrm{C}$. Badania przeprowadzone na próbkach rdzeniowych dowiodly, że w temperaturze $350^{\circ} \mathrm{C}$ zachodzi desorpcja całego spektrum węglowodorów, w tym również związków długołańcuchowych, które nie zawsze ulegają desorpcji w $300^{\circ} \mathrm{C}$. W temperaturze $350^{\circ} \mathrm{C}$ praktycznie nie pojawiają się jeszcze produkty pirolizy, co manifestuje się na chromatogramach brakiem (lub minimalną ilością) węglowodorów $\mathrm{C}_{1}-\mathrm{C}_{6}$. Należy zwrócić uwagę, że rozdział chromatograficzny produktów desorpcji materiału skalnego pozwala na wstępną charakterystykę akumulacji pod kątem zawartości i dystrybucji związków węglowodorowych, które mogą być desorbowane z próbek skał. 


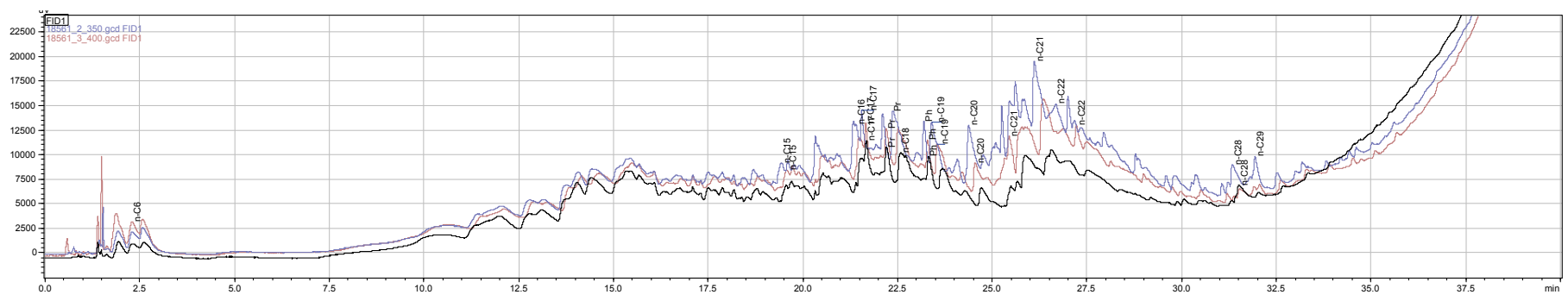

Rys. 1. Porównanie składu produktów pirolizy w temperaturach $300^{\circ} \mathrm{C}$ (czarna linia), $350^{\circ} \mathrm{C}$ (niebieska linia) i $400^{\circ} \mathrm{C}($ czerwona linia) skała o niewielkim nasyceniu węglowodorami (Rock-Eval $\mathrm{S}_{1}=0,38 \mathrm{mg} / \mathrm{g}$ )

Fig. 1. Comparison of products after pyrolysis at $300^{\circ} \mathrm{C}$ (black line), $350^{\circ} \mathrm{C}$ (blue line) and $400^{\circ} \mathrm{C}$ (red line) - rock with low saturation of hydrocarbons (Rock Eval $\mathrm{S}_{1}=0.38 \mathrm{mg} / \mathrm{g}$ )

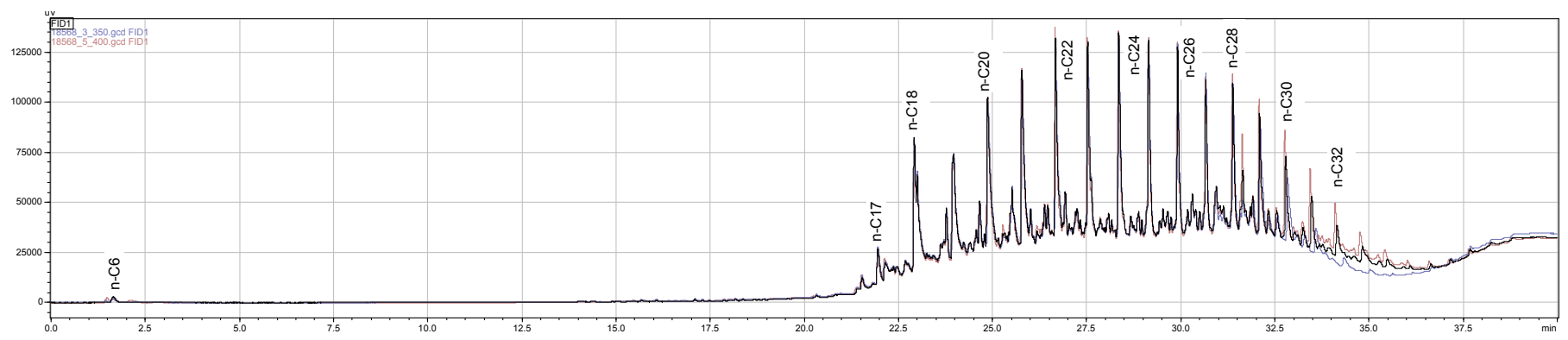

Rys. 2. Porównanie składu produktów pirolizy w temperaturach $300^{\circ} \mathrm{C}$ (czarna linia), $350^{\circ} \mathrm{C}$ (niebieska linia) i $400^{\circ} \mathrm{C}(\mathrm{czerwona}$ linia) skała o wysokim nasyceniu węglowodorami (Rock-Eval $\mathrm{S}_{1}=2,04 \mathrm{mg} / \mathrm{g}$ )

Fig. 2. Comparison of products after pyrolysis at $300^{\circ} \mathrm{C}$ (black line), $350{ }^{\circ} \mathrm{C}$ (blue line) and $400^{\circ} \mathrm{C}$ (red line) - rock with high saturation of hydrocarbons (Rock Eval $\mathrm{S}_{1}=2.04 \mathrm{mg} / \mathrm{g}$ )

Optymalne warunki desorpcji związków organicznych ze skał i gleb to temperatura $350^{\circ} \mathrm{C}$ i czas 1 minuta. Warunki te zastosowano w niniejszej pracy. Dla potwierdzenia słuszności wyboru na 2 próbkach rdzeni wykonano eksperymenty Py-GC/FID w temperaturach $300^{\circ} \mathrm{C}, 350^{\circ} \mathrm{C}$ i $400^{\circ} \mathrm{C}$. Jedna z badanych próbek (rys. 1) zawierała niewielkie ilości wolnych węglowodorów $\left(\mathrm{S}_{1}=0,38 \mathrm{mg} / \mathrm{g}\right)$, druga (rys. 2) pochodziła ze strefy akumulacji ropy naftowej $\left(\mathrm{S}_{1}=2,04 \mathrm{mg} / \mathrm{g}\right)$. W przypadku próbki o niewielkim nasyceniu temperatura desorpcji $350^{\circ} \mathrm{C}$ okazała się optymalna do scharakteryzowania uwalnianych węglowodorów. W przypadku próbki nasyconej ropą uzyskano identyczne (idealnie nałożone) chromatogramy dla wszystkich temperatur.

\section{Metodyka badań}

Na potrzeby niniejszej pracy badania zawartości wolnych związków organicznych w rdzeniach wiertniczych wykonywano trzema metodami:

- pirolizy połączonej z chromatografią gazową, z detekcją płomieniowo-jonizacyjną - Py-GC/FID;

- pirolizy Rock-Eval;

- ekstrakcji rozpuszczalnikowej - w celu oznaczenia zawartości ekstrahowalnej substancji organicznej (ESO).
Z pięciu ekstraktów wyizolowano frakcje węglowodorów nasyconych i poddano je analizie chromatograficznej GC-FID.

Badania metodą pirolizy sprzężonej z chromatografią gazową (Py-GC/FID) są wykonywane w Laboratorium Geochemii Nafty i Gazu INiG - PIB według procedury własnej (Kania i Janiga, 2015), przy użyciu systemu analitycznego składającego się z wielofazowego pirolizera Multi-Shot Pyrolyzer EGA/PY-3030D firmy Frontier Laboratories sprzężonego z chromatografem gazowym GC-2010 Plus firmy Shimadzu, wyposażonym w detektor płomieniowo-jonizacyjny (FID). W systemie, przed wejściem na kolumnę chromatograficzną, jest zainstalowana pułapka kriogeniczna, chłodzona ciekłym azotem dzięki połączeniu z wymrażarką MicroJet Cryo-Trap MJT-1030Ex.

Odpowiednią ilość próbki (5-20 mg, odwrotnie proporcjonalnie do zawartości substancji organicznej) odważano bezpośrednio $\mathrm{w}$ tygielku analitycznym, a następnie instalowano tygielek w próbniku i całość umieszczano w pirolizerze. Po wypłukaniu powietrza za pomocą helu, stosowanego jako gaz nośny ( 2 minuty, przepływ $50 \mathrm{ml} / \mathrm{min}$ ), próbka była wprowadzana do pieca pirolitycznego rozgrzanego do temperatury $350^{\circ} \mathrm{C}$, gdzie pozostawała $\mathrm{w}$ atmosferze helu przez 1 minutę. Produkty desorpcji analizowanej próbki gromadziły się w pułapce kriogenicznej, połączonej za pomocą interfejsu z kolumną chromatografu gazowego, zaś po rozdziale 
na kolumnie trafiały do detektora FID. Temperaturę interfejsu ustawiano na $250^{\circ} \mathrm{C}$.

Parametry pracy chromatografu:

- kolumna kapilarna Ultra Alloy-5 o długości 30,0 m, średnicy wewnętrznej $0,25 \mathrm{~mm}$, grubości filmu 0,25 $\mu \mathrm{m}$;

- detektor FID;

- gaz nośny - hel, o stałej prędkości przepływu - 1,98 ml/min;

- temperatura dozownika $250^{\circ} \mathrm{C}$;

- temperatura detektora FID $360^{\circ} \mathrm{C}$;

- program temperaturowy: $30^{\circ} \mathrm{C}-5 \mathrm{~min}$, gradient temperaturowy $10^{\circ} \mathrm{C} / \mathrm{min}$ do $360^{\circ} \mathrm{C}, 360^{\circ} \mathrm{C}-2 \mathrm{~min}$;

- $\quad$ split 10:1.

Pirolizę Rock-Eval (Lafargue et al., 1998; Behar et al., 2001) wykonano w analizatorze RE6 model Turbo $\mathrm{z}$ detektorem FID oraz z dwoma detektorami IR, stosując metodę BULK ROCK, cykl BASIC. Ekstrakcję skał (ESO) przeprowadzono w aparatach Soxhleta w ciągu 24 godzin, stosując jako rozpuszczalnik mieszaninę dichlorometan:metanol (93:7). Z otrzymanych ekstraktów wyizolowano metodą chromatografii kolumnowej frakcję węglowodorów nasyconych do analizy GC-FID.

Wyizolowana z ekstraktu bitumicznego frakcja węglowodorów nasyconych została poddana analizie chromatograficznej GC-FID w celu porównania dystrybucji węglowodorów z wynikami Py-GC/FID. W Laboratorium Geochemii Nafty i Gazu INiG - PIB analiza GC-FID frakcji nasyconej jest wykonywana na chromatografie Trace GC Ultra z zastosowaniem kolumny kapilarnej Rtx-1 (105 m × 0,32 mm × $1 \mu \mathrm{m})$ $\mathrm{i}$ helu jako gazu nośnego, w programie temperaturowym: start $60 \mathrm{C}$, narost temperatury $4 \mathrm{C} / \mathrm{min}$ do $310 \mathrm{C}$, izotermiczne wygrzewanie w temperaturze 310 C przez 25 min. Układ analityczny współpracuje z programem komputerowym Chrom-Card.

\section{Badania i interpretacja wyników}

Do badań pobrano 20 próbek rdzeni z otworu L-1. Dziewiętnaście $\mathrm{z}$ nich pochodziło $\mathrm{z}$ utworów dolomitu głównego z głębokości 3242,50$3285,60 \mathrm{~m}$, a jedną próbkę pobrano z piaskowców górnej serii autunu z głębokości 3453,35 m.

Według danych z dokumentacji geologicznej - utwory dolomitu głównego, występujące w otworze L-1 na głębokości 3242-3298 m, są nasycone węglowodorami, zarówno gazem, jak i ropą naftową. Niewielki przypływ ropy naftowej uzyskano już w trakcie wiercenia z interwału 3242-3260 m, zaś po zabiegach otworowych z perforacji interwałów 3250-3275 m i 3280-3286 m nastąpił przemysłowy przypływ ropy naftowej.

Celem pracy była ocena przydatności metody desorpcji z zastosowaniem Py-GC/FID do określania nasyceń w profilu odwiertu. W związku z tym wszystkie próbki analizowano metodą pirolitycznej chromatografii gazowej. Porównawczo wszystkie próbki poddano pirolizie Rock-Eval, a dla większości oznaczono zawartość ESO (18/20 próbek). Z pięciu ekstraktów wyizolowano frakcje węglowodorów nasyconych i poddano je analizie chromatograficznej GC-FID w celu porównania dystrybucji n-alkanów z zapisem chromatogramu uzyskanego w wyniku desorpcji Py-GC/FID.

Wyniki badań zawartości wolnych związków organicznych, które zostały uwolnione ze skały metodami desorpcji lub ekstrakcji, zestawiono w tabeli 1.

Metoda Py-GC/FID jest trudna do ilościowego skalibrowania ze względu na mnogość i różnorakość związków organicznych uwalnianych ze skały podczas desorpcji lub pirolizy oraz wpływ matrycy skalnej, zaburzający zapis chromatogramu. $\mathrm{Z}$ tego powodu brak jest uniwersalnych wzorców

Tabela 1. Zawartość wolnych związków organicznych w rdzeniach z otworu L-1 Table 1. The content of free organic compounds in the cores from the L-1 well

\begin{tabular}{|c|c|c|c|c|}
\hline \multirow{2}{*}{ Kod próbki } & Głębokość & QPy-GC & ESO & $S_{1}$ \\
\hline & [m] & [pow./mg] & [ppm] & {$[\mathrm{mg} / \mathrm{g}]$} \\
\hline 18561 & 3242,50 & 56 & n.b. & 0,38 \\
\hline 18562 & 3245,20 & 1087 & 2701 & 1,88 \\
\hline 18564 & 3248,70 & 1088 & 2302 & 2,53 \\
\hline 18567 & 3256,45 & 3644 & 4440 & 3,67 \\
\hline 18568 & 3257,50 & 974 & 2357 & 2,04 \\
\hline 18570 & 3260,20 & 1889 & 2656 & 2,57 \\
\hline 18571 & 3262,15 & 1417 & 1956 & 1,93 \\
\hline 18573 & 3266,50 & 659 & 2084 & 1,44 \\
\hline 18574 & 3268,75 & 866 & 2155 & 1,83 \\
\hline 18575 & 3270,80 & 1471 & 2361 & 2,66 \\
\hline 18576 & 3273,60 & 2087 & 3372 & 2,71 \\
\hline 18577 & 3276,25 & 1444 & 3188 & 2,44 \\
\hline 18579 & 3279,85 & 1410 & 3198 & 2,62 \\
\hline 18580 & 3281,35 & 7021 & 7584 & 6,04 \\
\hline 18581 & 3281,80 & 13855 & 16235 & 12,8 \\
\hline 18582 & 3282,15 & 4695 & 5765 & 4,87 \\
\hline 18583 & 3283,30 & 2459 & 4974 & 4,04 \\
\hline 18584 & 3283,85 & 4276 & 7218 & 6,04 \\
\hline 18585 & 3285,60 & 5909 & 5710 & 5,66 \\
\hline 18586 & 3453,35 & 0 & n.b. & 0,01 \\
\hline
\end{tabular}

QPy-GC - sumaryczna ilość produktów desorpcji Py-GC/FID w temperaturze $350^{\circ} \mathrm{C}$, wyrażona jako wskaźnik powierzchni pików przypadającej na $1 \mathrm{mg}$ skały, ESO - zawartość ekstrahowalnej substancji organicznej, $\mathrm{S}_{1}$ - zawartość wolnych węglowodorów obecnych w próbce, uwolnionych w trakcie pirolizy Rock-Eval w temperaturze $300^{\circ} \mathrm{C}$ 

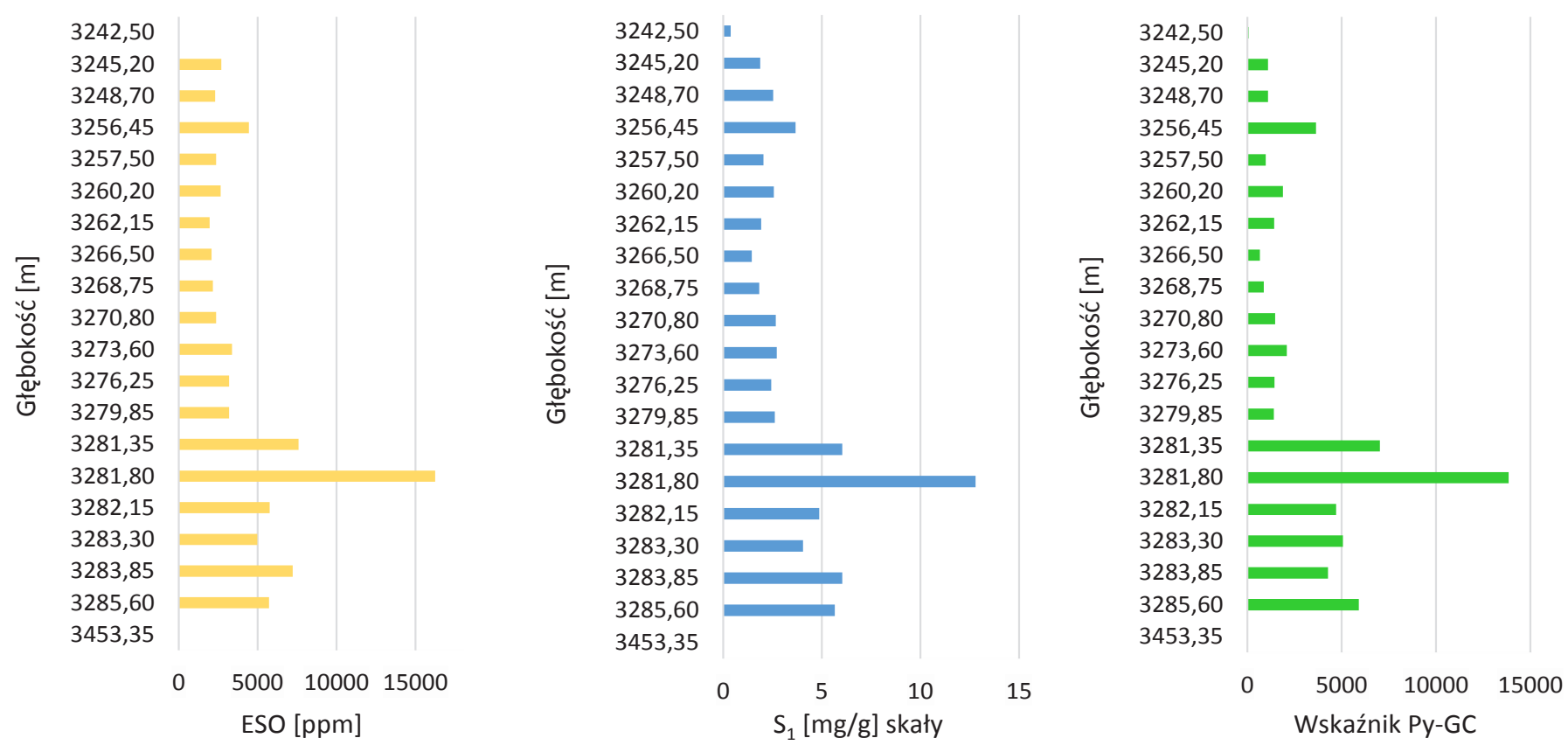

Rys. 3. Rozkład zawartości wolnej substancji organicznej w profilu otworu L-1 - wyniki uzyskane trzema różnymi metodami

Fig. 3. The distribution of the free organic matter content in the L-1 well profile - results obtained by three different methods

kalibracyjnych. Generalnie natomiast w chromatografii gazowej obowiązuje zasada, że pole powierzchni piku na chromatogramie jest wprost proporcjonalne do zawartości składnika w analicie. Stosując tę zasadę jako miarę całkowitej zawartości produktów desorpcji uzyskanych z 1 mg próbki, obliczono wskaźnik będący stosunkiem całkowitego pola powierzchni pików na chromatogramie do wielkości analizowanej naważki (QPy-GC). Tym samym przyjęto, że wskaźnik pola powierzchni pików przypadający na miligram skały poddawanej pirolizie jest miarą całkowitej zawartości desorbowanych związków. Umożliwia to analizę porównawczą badanych próbek oraz dokonanie korelacji wyników otrzymanych różnymi metodami.

Wyniki te dają spójny obraz zmian nasycenia węglowodorami w profilu otworu (rys. 3), lokując w każdym przypadku główną strefę złożową dolomitu głównego w otworze L-1 w przedziale głębokości 3281,35-3285,60 m i pokazując niższe nasycenie węglowodorami w przedziale głębokości 3245,20-3279,85 m. W próbce $\mathrm{z}$ utworów autunu (głęb. 3453,35 m) stwierdzono śladową zawartość węglowodorów. Na tej podstawie można wnioskować o równocenności wyników metody desorpcji Py-GC/FID z wynikami pirolizy Rock-Eval i z wynikami badania zawartości ESO metodą ekstrakcji rozpuszczalnikowej. Liniowe korelacje (współczynnik determinacji $\left.\mathrm{R}^{2}>0,95\right)$ zawartości wolnych węglowodorów $\mathrm{S}_{1} \mathrm{z}$ wynikami ESO i wskaźnikiem desorpcji Py-GC/FID (QPy-GC) pokazują również kompatybilność wyników dwóch ostatnich metod z wynikami pirolizy Rock-Eval (rys. 4), co wykazano już we wcześniejszych pracach prowadzonych w Laboratorium Geochemii Nafty i Gazu w kooperacji z Politechniką Śląską (Labus et al., 2018). Nieco gorszą, chociaż nadal zadowalającą korelację $\left(\mathrm{R}^{2}=0,9492\right)$ uzyskano, porównując wyniki ilości wolnych związków organicznych uwalnianych przez desorpcję Py-GC/FID z zawartością ESO w rdzeniach z otworu L-1 (rys. 5). Należy tu podkreślić, że każda z zastosowanych metod ma nieco inną specyfikę, w związku z czym otrzymane wyniki nie mogą być identyczne. W metodach pirolitycznych czynnikiem powodującym desorpcję jest jedynie temperatura, gdyż procesy zachodzą w środowisku gazu obojętnego. W pirolizie Rock-Eval pik $\mathrm{S}_{1}$, odzwierciedlający zawartość wolnych węglowodorów, jest rejestrowany w temperaturze $300^{\circ} \mathrm{C}$, podczas gdy w eksperymentach Py-GC/FID ustalono temperaturę $350^{\circ} \mathrm{C}$ jako granicę desorpcji wolnych węglowodorów. Z kolei ekstrakcja rozpuszczalnikowa jest prowadzona $\mathrm{w}$ temperaturze wrzenia mieszaniny ekstrakcyjnej (około $40^{\circ} \mathrm{C}$ ), za to przez nieporównywalnie dłuższy czas. W procesie tym istotny wpływ ma oddziaływanie rozpuszczalnika, w wyniku którego z materiału skalnego są uwalniane liczne związki organiczne o skomplikowanej budowie (np. żywice i asfalteny), które mogą zostać przeprowadzone w stan gazowy jedynie na drodze dekompozycji cząsteczek o wysokiej masie cząsteczkowej. Nie mogą być uwalniane w procesach desorpcji bez udziału rozpuszczalnika.

Po potwierdzeniu przydatności desorpcji Py-GC do oceny zawartości wolnych związków organicznych zawartych w rdzeniach wiertniczych wykonano ocenę metody w aspekcie charakterystyki uwalnianych produktów. W produktach desorpcji dominują węglowodory z szeregu homologicznego n-alkanów i izoprenoidów. W geochemii naftowej podstawowym narzędziem do charakterystyki tej grupy związków jest analiza chromatograficzna GC-FID, uzupełniana analizą GC/MS 


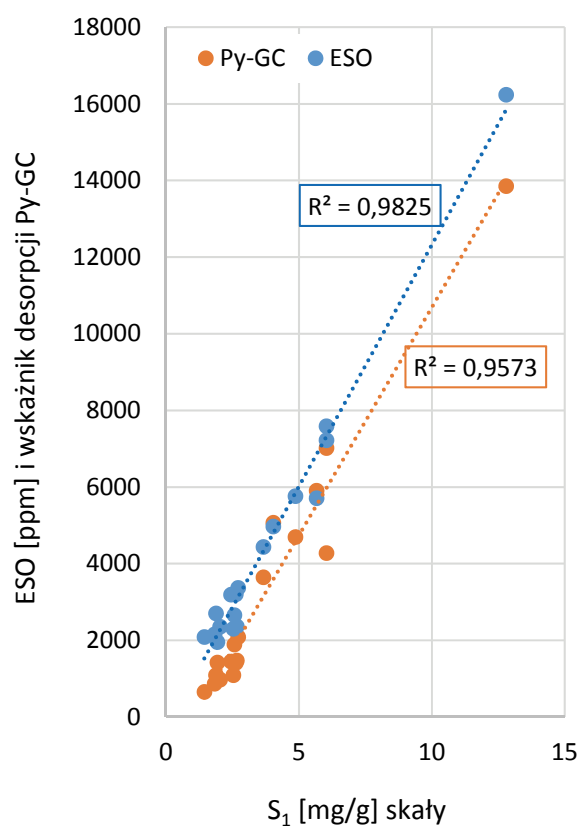

Rys. 4. Korelacja ilości wolnych związków organicznych uwalnianych podczas pirolizy i ekstrakcji z rdzeni z otworu L-1

Fig. 4. Correlation of the amount of free organic compounds released by pyrolysis and extraction from cores from the L-1 well

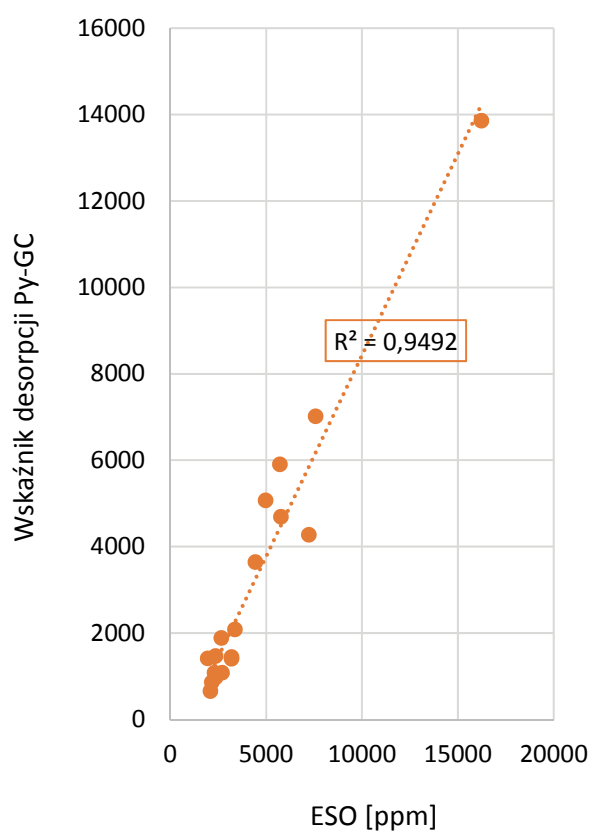

Rys. 5. Korelacja ilości wolnych związków organicznych uwalnianych przez desorpcję Py-GC/FID z zawartością ESO w rdzeniach z otworu L-1

Fig. 5. Correlation of the amount of free organic compounds released by Py-GC/FID desorption with ESO content in cores from the L-1 well

(Matyasik, 2011). Ta druga służy jednak głównie do badania obecności i zawartości biomarkerów, które w większości nie są identyfikowane na chromatogramach GC-FID i pirogramach Py-GC/FID, lecz wymagają zastosowania detektora spektrometrii mas.
Analiza chromatograficzna GC-FID frakcji węglowodorów nasyconych wyizolowanych z ekstraktu bitumicznego dostarcza informacji o zakresie szeregu homologicznego n-alkanów obecnych w próbce oraz o obecności i relatywnych ilościach izoprenoidów. Zazwyczaj cechą charakterystyczną dystrybucji węglowodorów parafinowych jest wyraźna przewaga n-alkanów nad izoprenoidami. Dla geochemii naftowej istotne jest stwierdzenie obecności pristanu i fitanu i oszacowanie ich wzajemnego stosunku oraz stosunku tych izoalkanów do ich homologów nierozgałęzionych $\left(\mathrm{Pr} / \mathrm{nC}_{17} \mathrm{i} \mathrm{Ph} / \mathrm{nC}_{18}\right)$. Do interpretacji wyników uzyskanych $\mathrm{z}$ analizy chromatograficznej GC-FID frakcji nasyconej posługujemy się ponadto wskaźnikami preferencji n-alkanów o nieparzystej liczbie atomów węgla nad n-alkanami o parzystej liczbie atomów węgla (carbon preference index - CPI) obliczanymi trzema sposobami, dla różnych zakresów szeregu homologicznego: $\mathrm{CPI}_{\text {(Total) }}$ obejmuje zakres szeregu homologicznego n-alkanów o liczbie węgla w łańcuchu od $\mathrm{C}_{17}$ do $\mathrm{C}_{31}, \mathrm{CPI}_{(17-23)}$, obejmujący zakres n-alkanów krótkołańcuchowych od $\mathrm{C}_{17}$ do $\mathrm{C}_{23}$, przydatny jest do charakterystyki morskiej materii organicznej, $\mathrm{CPI}_{(25-31)}$, obliczany dla n-alkanów długołańcuchowych od $\mathrm{C}_{25}$ do $\mathrm{C}_{31}$, umożliwia charakterystykę materii organicznej pochodzenia lądowego. Analiza wszystkich powyższych wskaźników daje wstępne informacje odnośnie do typu genetycznego źródłowej materii organicznej, stopnia jej dojrzałości termicznej oraz środowiska depozycji.

W celu porównania dystrybucji n-alkanów z zapisem chromatogramu uzyskanego w wyniku desorpcji metodą Py-GC/FID - z pięciu ekstraktów ESO wyizolowano frakcje węglowodorów nasyconych i poddano je analizie chromatograficznej GC-FID. Chromatogramy GC-FID frakcji nasyconej ekstraktu (rys. 6A, 7A, 8A, 9A, 10A) oraz chromatogramy produktów desorpcji Py-GC/FID (rys. 6B, 7B, 8B, 9B, 10B) zestawiono parami dla tych samych próbek.

Analiza GC-FID frakcji węglowodorów nasyconych ekstraktów z otworu L-1 wykazała obecność szeregu homologicznego n-alkanów w zakresie $\mathrm{C}_{15}-\mathrm{C}_{35}$, $\mathrm{z}$ maksimum przy węglu $\mathrm{C}_{20}$. Wartości wskaźników CPI dla całego szeregu homologicznego pokazują przewagę n-alkanów o parzystej liczbie atomów węgla w cząsteczce, jeszcze wyraźniejsza jest ta przewaga w zakresie węglowodorów krótkołańcuchowych (tab. 2). Około trzykrotna przewaga zawartości fitanu nad pristanem (Pr/Ph od 0,22 do 0,42) wskazuje na redukcyjne warunki środowiska depozycji morskiej materii organicznej. W takim przypadku $\mathrm{CPI}_{25-31}$ jest mało użyteczny. Stosunek izoprenoidów do sąsiadujących n-alkanów, oceniany na podstawie relacji $\mathrm{Pr} / \mathrm{n}-\mathrm{C}_{17}$ i Ph/n- $\mathrm{C}_{18}$, świadczy o dojrzałości substancji organicznej, z której zostały wygenerowane węglowodory, na poziomie głównej fazy okna ropnego.

Podjęto również próbę obliczenia analogicznych wskaźników z chromatogramów uzyskanych po desorpcji 


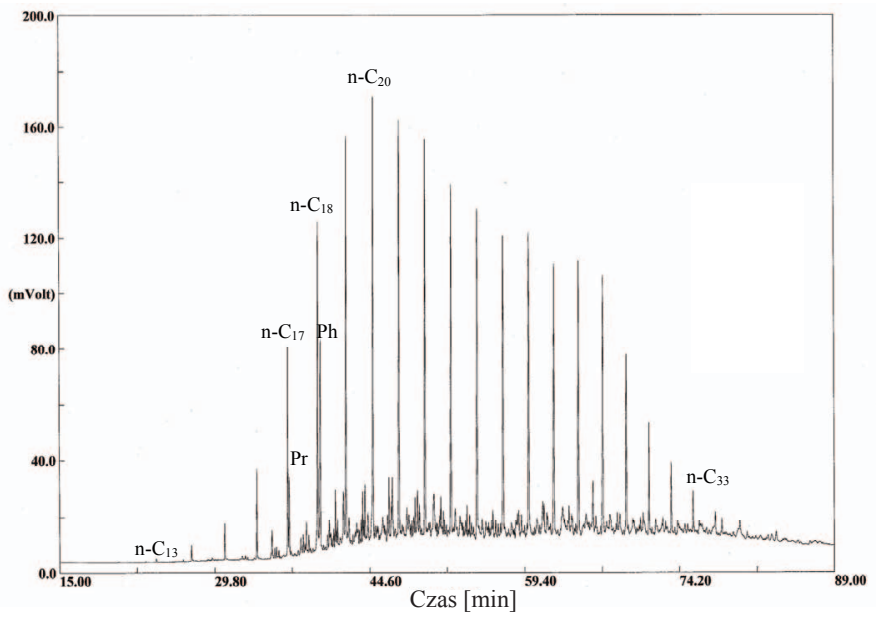

Rys. 6A. Dystrybucja węglowodorów frakcji nasyconej ekstraktu z rdzenia z głębokości $3248,70 \mathrm{~m}$

Fig. 6A. Distribution of saturated hydrocarbons fraction of the extract from the core from the depth of $3248.70 \mathrm{~m}$

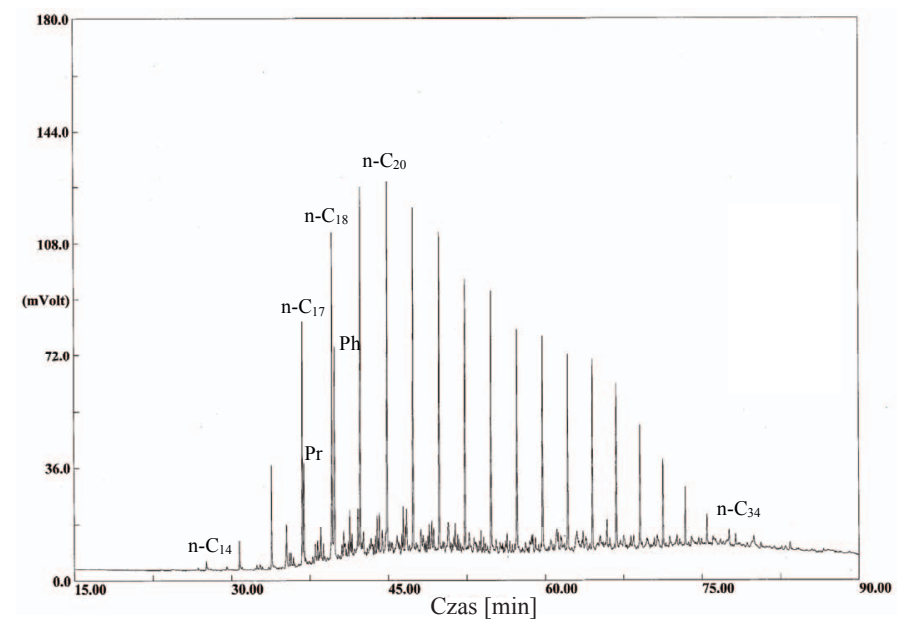

Rys. 7A. Dystrybucja węglowodorów frakcji nasyconej ekstraktu z rdzenia z głębokości $3257,50 \mathrm{~m}$

Fig. 7A. Distribution of saturated hydrocarbons fraction of the extract from the core from the depth of $3257.50 \mathrm{~m}$

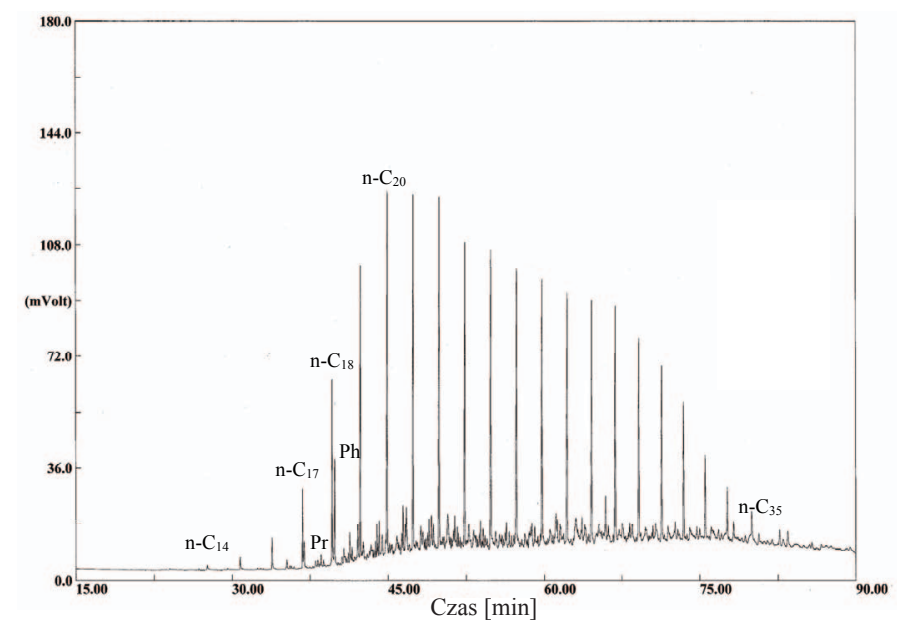

Rys. 8A. Dystrybucja węglowodorów frakcji nasyconej ekstraktu z rdzenia z głębokości 3260,20 m

Fig. 8A. Distribution of saturated hydrocarbons fraction of the extract from the core from the depth of $3260.20 \mathrm{~m}$

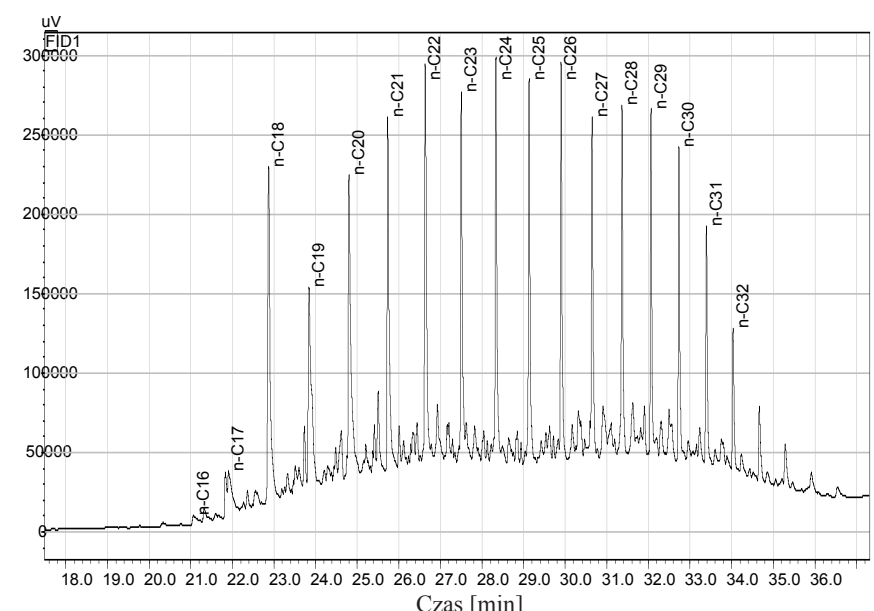

Rys. 6B. Dystrybucja produktów desorpcji Py-GC $\left(350^{\circ} \mathrm{C}\right)$ rdzenia z głębokości 3248,70 m

Fig. 6B. Distribution of Py-GC $\left(350^{\circ} \mathrm{C}\right)$ core desorption products from the depth of $3248.70 \mathrm{~m}$

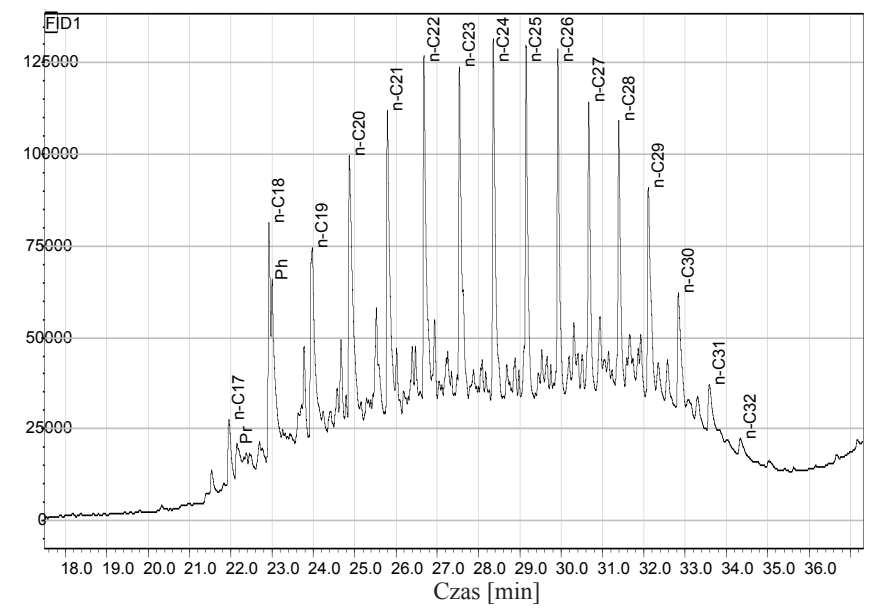

Rys. 7B. Dystrybucja produktów desorpcji Py-GC $\left(350^{\circ} \mathrm{C}\right)$ rdzenia z głębokości $3257,50 \mathrm{~m}$

Fig. 7B. Distribution of Py-GC $\left(350^{\circ} \mathrm{C}\right)$ core desorption products from the depth of $3257.50 \mathrm{~m}$

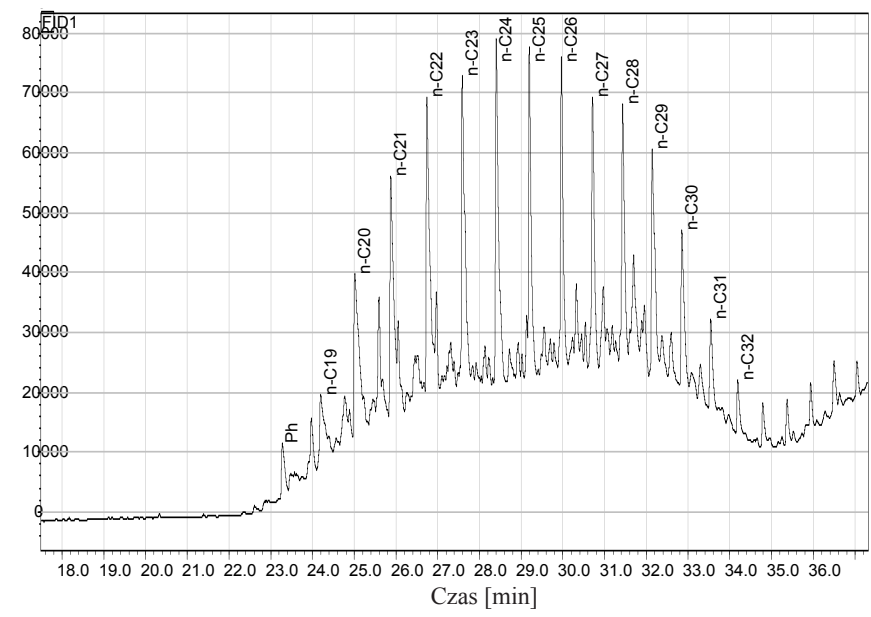

Rys. 8B. Dystrybucja produktów desorpcji Py-GC $\left(350^{\circ} \mathrm{C}\right)$ rdzenia z głębokości 3260,20 m

Fig. 8B. Distribution of Py-GC $\left(350^{\circ} \mathrm{C}\right)$ core desorption products from the depth of $3260.20 \mathrm{~m}$ 


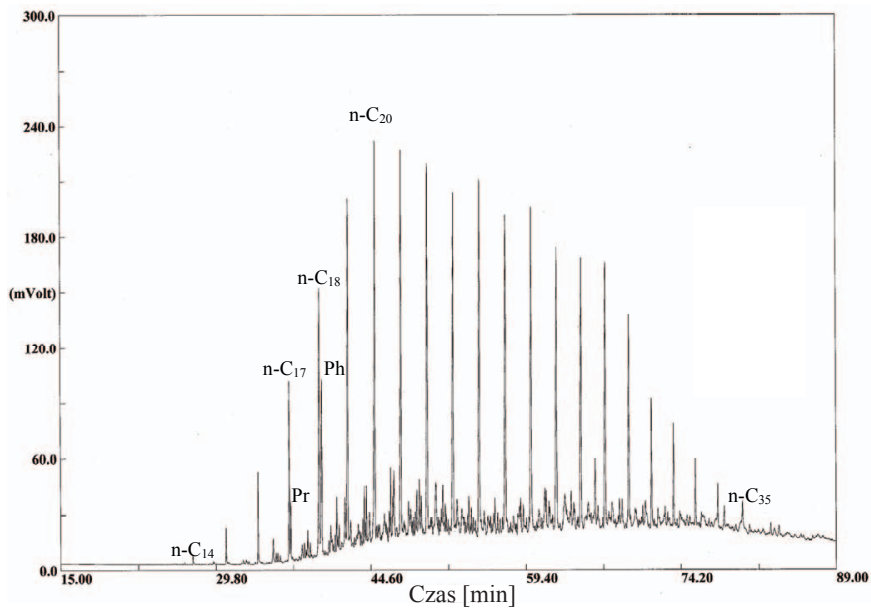

Rys. 9A. Dystrybucja węglowodorów frakcji nasyconej ekstraktu z rdzenia z głębokości $3270,80 \mathrm{~m}$

Fig. 9A. Distribution of saturated hydrocarbons fraction of the extract from the core from the depth of $3270.80 \mathrm{~m}$

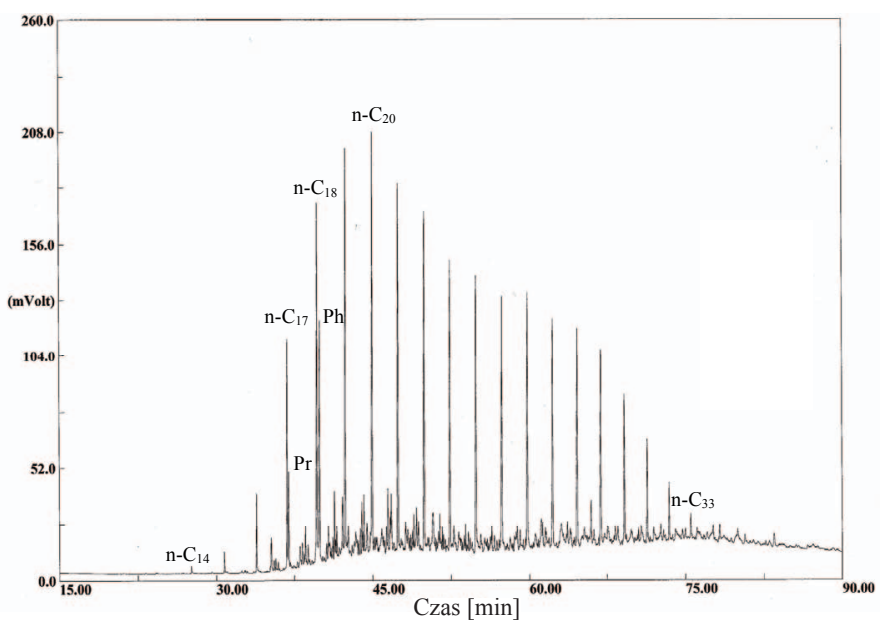

Rys. 10A. Dystrybucja węglowodorów frakcji nasyconej ekstraktu z rdzenia z głębokości 3285,60 m

Fig. 10A. Distribution of saturated hydrocarbons fraction of the extract from the core from the depth of $3285.60 \mathrm{~m}$

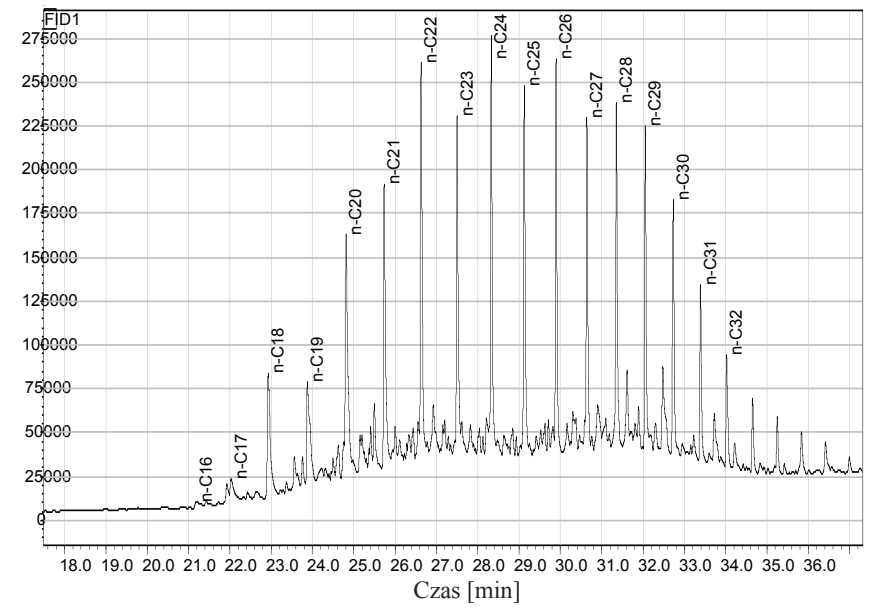

Rys. 9B. Dystrybucja produktów desorpcji Py-GC $\left(350^{\circ} \mathrm{C}\right)$ rdzenia z głębokości 3270,80 m

Fig. 9B. Distribution of Py-GC $\left(350^{\circ} \mathrm{C}\right)$ core desorption products from the depth of $3270.80 \mathrm{~m}$

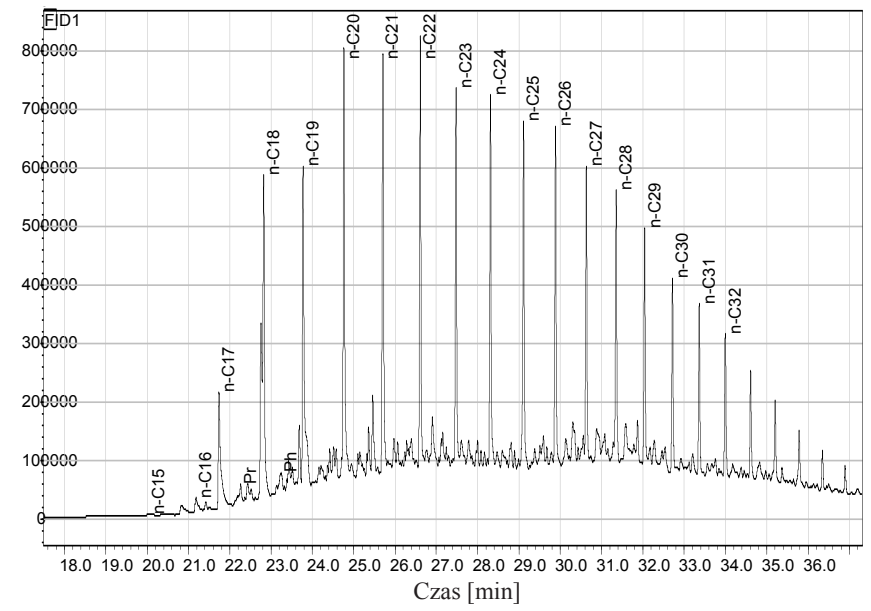

Rys. 10B. Dystrybucja produktów desorpcji Py-GC $\left(350^{\circ} \mathrm{C}\right)$ rdzenia $\mathrm{z}$ głębokości 3285,60 m

Fig. 10B. Distribution of Py-GC $\left(350^{\circ} \mathrm{C}\right)$ core desorption products from the depth of $3285.60 \mathrm{~m}$

Tabela 2. Wskaźniki geochemiczne obliczone na podstawie analizy GC-FID frakcji nasyconej ekstraktów z rdzeni z dolomitu głównego otworu L-1

Table 2. Geochemical indices calculated on the basis of the GC-FID analysis of the saturated fraction of the extracts from the Main Dolomite core of the L-1 well

\begin{tabular}{|c|c|c|c|c|c|c|c|}
\hline Kod próbki & $\begin{array}{c}\text { Głębokość } \\
{[\mathbf{m}]}\end{array}$ & $\mathbf{C P I}_{\text {total }}$ & $\mathbf{C P I}_{\mathbf{1 7 - 2 3}}$ & $\mathbf{P r} / \mathbf{P h}$ & $\mathbf{P r} / \mathbf{n}-\mathbf{C}_{\mathbf{1 7}}$ & $\mathbf{P h} / \mathbf{n}-\mathbf{C}_{\mathbf{1 8}}$ & $\mathbf{n}_{\mathbf{m a x}}$ \\
\hline \hline 18564 & 3248,70 & 0,90 & 0,88 & 0,25 & 0,50 & 0,98 & $\mathrm{n}-\mathrm{C}_{20}$ \\
\hline 18568 & 3257,50 & 0,89 & 0,90 & 0,38 & 0,56 & 0,90 & $\mathrm{n}-\mathrm{C}_{20}$ \\
\hline 18570 & 3260,20 & 0,94 & 0,87 & 0,36 & 0,29 & 0,32 & $\mathrm{n}-\mathrm{C}_{20}$ \\
\hline 18575 & 3270,80 & 0,89 & 0,90 & 0,22 & 0,43 & 0,91 & $\mathrm{n}-\mathrm{C}_{20}$ \\
\hline 18585 & 3285,60 & 0,80 & 0,76 & 0,26 & 0,51 & 0,91 & $\mathrm{n}-C_{20}$ \\
\hline
\end{tabular}

metodą Py-GC/FID (tab. 3). Ze względu na wpływ matrycy skalnej nie udało się dla badanych próbek uzyskać dokładnego rozdziału pristanu i fitanu od sąsiadujących z nimi n-alkanów. Nie było więc możliwe obliczenie wskaźników izoprenoidowych. Natomiast indeksy CPI (zarówno CPI $\mathrm{total}_{\text {, }}$ jak i $\mathrm{CPI}_{17-23}$ ) generalnie potwierdziły przewagę n-alkanów o parzystej liczbie atomów węgla w łańcuchu nad homologami o liczbie nieparzystej. Odstępstwo odnotowano jedynie 
Tabela 3. Wskaźniki geochemiczne obliczone na podstawie dystrybucji węglowodorów uzyskanych podczas desorpcji rdzeni z dolomitu głównego otworu L-1 (metoda Py-GC/FID)

Table 3. Geochemical indices calculated on the basis of hydrocarbon distribution obtained as the result of desorption of cores from the Main Dolomite core of the L-1 well (Py-GC/FID method)

\begin{tabular}{|c|c|c|c|c|}
\hline Kod próbki & $\begin{array}{c}\text { Głębokość } \\
{[\mathbf{m}]}\end{array}$ & $\mathbf{C P I}_{\text {total }}$ & $\mathbf{C P I}_{\mathbf{1 7 - 2 3}}$ & $\mathbf{n}-\mathbf{C}_{\max }$ \\
\hline \hline 18564 & 3248,70 & 0,86 & 0,78 & $\mathrm{n}-C_{20}$ \\
\hline 18568 & 3257,50 & 0,96 & 0,96 & $\mathrm{n}-C_{20}$ \\
\hline 18570 & 3260,20 & 0,93 & 0,92 & $\mathrm{n}-C_{22}$ \\
\hline 18575 & 3270,80 & 0,89 & 0,87 & $\mathrm{n}-C_{22}$ \\
\hline 18585 & 3285,60 & 1,09 & 1,20 & $\mathrm{n}-C_{20}$ \\
\hline
\end{tabular}

w przypadku próbki z głębokości 3285,60 m. Jednocześnie dla tej próbki uzyskano największe podobieństwo dystrybucji węglowodorów na chromatogramach GC-FID i Py-GC/FID (rys. 10A, 10B).

W analizie GC-FID we wszystkich badanych próbkach stwierdzono najwyższą zawartość n-alkanu $\mathrm{n}-\mathrm{C}_{20}$. Wynikało to zarówno z porównania wielkości powierzchni pików, jak i było widoczne na chromatogramach (rys. 6A, 7A, 8A, 9A, 10A). Na chromatogramach produktów desorpcji Py-GC/FID (rys. 6B, 7B, 8B, 9B, 10B) maksima wydają się przesunięte w stronę wyższych węglowodorów $\mathrm{C}_{22}$ lub $\mathrm{C}_{24}$, zawsze jednak pozostaje to homolog o parzystej liczbie atomów węgla w łańcuchu. Okazuje się jednak, że na podstawie pól powierzchni pików, które to pola są miarą zawartości poszczególnych składników, wyniki desorpcji Py-GC/FID w trzech próbkach również identyfikują $n-\mathrm{C}_{20}$ jako $\mathrm{C}_{\max }$, a w pozostałych dwóch próbkach wskazują na n- $\mathrm{C}_{22}$ (tab. 3). Na chromatogramach Py-GC/FID wyraźniej widoczna jest przewaga n-alkanów o parzystej liczbie atomów węgla nad nieparzystymi, niż można to zaobserwować na chromatogramach uzyskanych metodą GC-FID. Szczególnie wyraźnie widać to na chromatogramach próbek z głębokości 3248,70 m (rys. 6B), $3257,50 \mathrm{~m}$ (rys. 7B) i 3270,80 m (rys. 9B).

Warto zwrócić uwagę na dosyć wysoki pik pomiędzy n- $\mathrm{C}_{28}$ i n- $\mathrm{C}_{29}$, widoczny na wszystkich chromatogramach GC-FID (rys. 6A, 7A, 8A, 9A, 10A), jak i na chromatogramach Py-GC/FID, na których jest on w trzech przypadkach bardzo wyraźny (rys. 7B, 8B, 9B), a w dwóch przypadkach nieco niższy (rys. 6B, 10B). Jest to prawdopodobnie $\mathrm{C}_{29}$ norhopan $\left(\mathrm{C}_{29} \mathrm{NH}\right)$, biomarker charakterystyczny dla materii organicznej deponowanej w środowisku węglanowym, który był identyfikowany w tym miejscu na chromatogramach GC-FID frakcji nasyconej bituminów wyekstrahowanych z rdzeni pochodzących z dolomitu głównego Niżu Polskiego (Matyasik, 2011).

Na podstawie wyników przeprowadzonych badań, pomimo pewnych rozbieżności, należy uznać, że dystrybucja produktów desorpcji Py-GC/FID skał w $350^{\circ} \mathrm{C}$ dostarcza podobnych informacji jak analiza chromatograficzna GC-FID frakcji węglowodorów nasyconych ekstraktu bitumicznego. W przypadku niezgodności jako bardziej miarodajne należy traktować wyniki analizy GC-FID, gdyż zostały one uzyskane dla czystej, wyizolowanej frakcji. Wyniki desorpcji Py-GC/FID mogą być obarczone większym błędem ze względu na wpływ matrycy skalnej, objawiający się między innymi ,garbem”, czyli podniesieniem linii bazowej na chromatogramie, dostarczają jednak podobnych informacji bez konieczności wstępnej preparatyki chemicznej materiału rdzeniowego, co znacznie skraca czas i obniża koszty analizy.

\section{Podsumowanie}

Celem przedstawionej pracy było sprawdzenie możliwości zastosowania nowej, alternatywnej dla pirolizy Rock-Eval i ekstrakcji rozpuszczalnikowej, szybkiej metody oceny typu nasyceń, wykorzystującej jako narzędzie pirolizę połączoną z chromatografią gazową Py-GC/FID, której wyniki mogą służyć do typowania poziomów do bardziej szczegółowych badań.

W tym celu wykonano badania porównawcze materiału skalnego trzema metodami analitycznymi: powszechnie stosowanymi - pirolizą Rock-Eval i metodą ekstrakcji rozpuszczalnikowej oraz niewykorzystywaną dotychczas do tego celu metodą desorpcji Py-GC/FID. Ocenie podlegała zawartość wolnej substancji organicznej uwalnianej podczas desorpcji Py-GC w $350^{\circ} \mathrm{C}$ w stosunku do zawartości ekstrahowalnej substancji organicznej ESO oraz ilości wolnych węglowodorów $\left(\mathrm{S}_{1}\right)$ wydzielanych podczas pirolizy Rock-Eval. Przeprowadzone eksperymenty udowodniły dobrą korelację wyników uzyskanych tymi trzema metodami. Wyniki wszystkich metod pokazują analogiczny rozkład nasyceń w profilu opróbowanego otworu L-1.

Metoda Py-GC/FID ma tę przewagę nad pozostałymi dwiema metodami, że otrzymany chromatogram pokazuje dystrybucję desorbowanych węglowodorów, co pozwala na wstępną charakterystykę akumulacji. W geochemii naftowej ocenę dystrybucji węglowodorów przeprowadza się na podstawie analizy GC-FID frakcji nasyconej ekstraktu bitumicznego. Dla kilku badanych rdzeni wykonano analizy chromatograficzne GC-FID frakcji nasyconej ESO i obliczono na ich podstawie wskaźniki geochemiczne. Wyniki porównania wykazały generalnie podobieństwo dystrybucji węglowodorów, a nawet dla niektórych próbek zgodność obliczonych wskaźników. Najważniejsze informacje, tzn. zakres szeregu homologicznego, wartości wskaźników CPI i położenie maksimum, dla większości próbek były zgodne. Mankamentem Py-GC/FID surowego materiału skalnego jest słabe rozdzielenie pristanu i fitanu od 


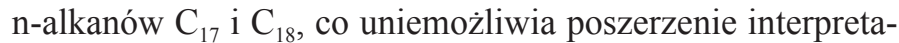
cji o wskaźniki izoprenoidowe ( $\mathrm{Pr} / \mathrm{Ph}, \mathrm{Pr} / \mathrm{n}-\mathrm{C}_{17}$ i Ph/n- $\left.\mathrm{C}_{18}\right)$. Tę lukę być może uda się uzupełnić po optymalizacji parametrów analizy chromatograficznej otrzymanych pirolizatów. Pomimo pewnych rozbieżności należy uznać, że dystrybucja produktów desorpcji Py-GC/FID skał w $350^{\circ} \mathrm{C}$ pozwala na uzyskanie części informacji dostarczanych przez analizę chromatograficzną GC-FID frakcji nasyconej ekstraktu bitumicznego bez konieczności wstępnej preparatyki chemicznej materiału skalnego, co znacznie skraca czas i obniża koszty analizy. Metoda stanowi więc bardzo dobre narzędzie do typowania próbek do dalszych badań (np. analizy biomarkerów, analiz izotopowych). Można zatem uznać, że opisana metoda desorpcji Py-GC/FID pozwoli na wstępną ocenę przewiercanych profili otworów po kątem charakteru nasyceń węglowodorami.

Autorzy składają podziękowania Dyrekcji PGNiG SA za udostępnienie informacji geologicznej i próbek rdzeni do badań realizowanych w ramach niniejszej pracy.

Artykuł powstał na podstawie pracy statutowej pt.: Ocena wykorzystania desorpcji termicznej do wyznaczania charakteru nasyceń w profilu odwiertu - praca INiG - PIB na zlecenie MNiSW; nr zlecenia: 0048/SG/2018, nr archiwalny: DK-4100-0048/2018.

\section{Literatura}

Abbassi S., Edwards D.S., George S.C., Volk H., Mahlstedt N., Primio di R., Horsfield B., 2016. Petroleum potential and kinetic models for hydrocarbon generation from the Upper Cretaceous to Paleogene Latrobe Group coals and shales in the Gippsland Basin, Australia. Organic Geochemistry, 91: 54-67. DOI: 10.1016/j. org.chem.2015.11.001.

Behar F., Beaumont V., Penteado H.L. De B., 2001. Rock Eval 6 Technology: Performances and Developments. Oil \& Gas Science and Technology - Rev. IFP, 56(2): 111-134.

Bruan V., Halim M., Ziyad M., Largeau C., Ambles A., 2001. Characterization of the Moroccan Timahdit (X-layer) oil shale kerogen using pyrolysis and thermally assisted hydrolysis and methylation. Journal of Analytical and Applied Pyrolysis, 61: 165-179.

Challinor J.M., 2001. Thermally assisted hydrolysis and methylation (THM) reactions. Journal of Analytical and Applied Pyrolysis, 61: 1-2.

Gil-Moltó J., Varea M., Galindo N., Crespo J., 2009. Application of an automatic thermal desorption-gas chromatography-mass spectrometry system for the analysis of polycyclic aromatic hydrocarbons in airborne particulate matter. Journal of Chromatography A, 1216: 1285-1289.

Gonzalez-Vila F.J., Ambles A., Río del J.C., Grasset L., 2001. Characterisation and differentiation of kerogens by pyrolytic and chemical degradation techniques. Journal of Analytical and Applied Pyrolysis, 58-59: 315-328.

Górecki T., Poerschmann J., 2001. In-Column Pyrolysis: A New Approach to an Old Problem. Analytical Chemistry, 73: 2012-2017.

Hu G., Peng W., Yu C., 2017. Insight into the C8 light hydrocarbon compositional differences between coal-derived and oil-associated gases. Journal of Natural Gas Geoscience, 2: 157-163. DOI: 10.1016/j.jnggs.2017.08.001.

Ikeya K., Ishida Y., Ohtani H., Watanabe A., 2006. Effect of off-line methylation using carbanion and methyl iodide on pyrolysis-gas chromatographic analysis of humic and fulvic acids. Journal of Analytical and Applied Pyrolysis, 75: 174-180. DOI: 10.1016/j. jaap.2005.03.011.

Janiga M., Bieleń W., Kania M., Kierat M., Matyasik I., Spunda K., 2018. Badania składu izotopowego Py-GC/IRMS - układ „online” pirolizera, chromatografu gazowego i izotopowego spektrometru masowego. Międzynarodowa Konferencja NaukowoTechniczna „, Geopetrol 2018”. Materiały konferencyjne: 679-682.

Kania M., Janiga M., 2015. Wykorzystanie pirolitycznej chromatografii gazowej do określania składu produktów symulowanego procesu generowania węglowodorów. Nafta-Gaz, 10: 720-728. DOI: 10.18668/NG.2015.10.02.

Labus M., Kierat M., Matyasik I., Spunda K., Kania M., Janiga M., Bieleń W., 2018. Charakterystyka generacyjna warstw menilitowych w oparciu o zintegrowane wyniki analiz termicznych. Międzynarodowa Konferencja Naukowo-Techniczna , Geopetrol 2018”. Materiały konferencyjne: 673-678.

Lafargue E., Marquis F., Pillot D., 1998. Rock-Eval 6 applications in hydrocarbon exploration, production and soil contamination studies. Revue de l'Institut Français du Pétrole, 53: 421-437.

Matyasik I., 2011. Biomarkery w charakterystyce systemów naftowych. Prace Naukowe Instytutu Nafty i Gazu, 177: 1-220. ISSN 0209-0724.

Matyasik I., Kierat M., Kania M., Brzuszek P., 2017. Ocena jakościowa węglowodorów generowanych $\mathrm{z}$ różnego typu skał macierzystych oparta na wynikach badań PY-GC, Rock-Eval i Leco. Nafta-Gaz, 10: 719-729. DOI: 10.18668/NG.2017.10.01.

Matyasik I., Kierat M., Kania M., Janiga M., Bieleń W., Spunda K., Dziadzio P., 2018. Aplikacja metody PYGC do oceny zanieczyszczenia gleby związkami ropopochodnymi w rejonie naturalnych wycieków węglowodorów w Karpatach. Międzynarodowa Konferencja Naukowo-Techniczna ,, Geopetrol 2018”. Materiały konferencyjne: 687-693.

Meruva N.K., Metz L.A., Goode S.R., Morgan S.L., 2004. UV laser pyrolysis fast gas chromatography/time-of-flight mass spectrometry for rapid characterization of synthetic polymers: instrument development. Journal of Analytical and Applied Pyrolysis, 71: 313-325.

Milczarek J.M., Zięba-Palus J., Kościelniak P., 2006. Working out conditions of identification and comparative analysis of car paints by pyrolytic gas chromatography coupled with mass spectrometry (Py-GC-MS). Problems of Forensic Sciences, 67: 235-248.

Parsi Z., Hartog N., Górecki T., Poerschmann J., 2007. Analytical pyrolysis as a tool for the characterization of natural organic matter - A comparison of different approaches. Journal of Analytical and Applied Pyrolysis, 79: 9-15. DOI: 10.1016/j.jaap.2006.10.013.

Peacock P.M., McEwen C.N., 2006. Mass Spectrometry of Synthetic Polymers. Analytical Chemistry, 78: 3957-3964.

Pernot A., Ouvrard S., Leglize P., Faure P., 2013. Protective role of fine silts for PAH in a former industrial soil. Environmental Pollution, 179: 81-87.

Salinas S.A., Kusch P., Knupp G., Steinhaus J.H., Sülthaus D., 2016. Characterization and quantification of poly(acrylonitrile-co1,3-butadiene-co-styrene)/polyamide 6(ABS/PA6) blends using pyrolysis-gas chromatography (Py-GC) with different detector systems. Journal of Analytical and Applied Pyrolysis, 122: 452-457. DOI: 10.1016/j.jaap.2016.10.020.

Sessions A.L., 2006. Isotope-ratio detection for gas chromatography. Journal of Separation Science, 29: 1946-1967. 
Sobeih K.L., Baron M., Gonzalez-Rodriguez J., 2008. Recent trends and developments in pyrolysis-gas chromatography. Journal of Chromatography A, 1186: 51-66. DOI: 10.1016/j. chroma.2007.10.017.

Yokoi H., Nakase T., Goto K., Ishida Y., Ohtani H., Tsuge S.,

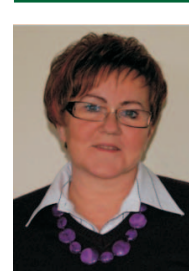

Dr hab. inż. Irena MATYASIK, prof. INiG - PIB

Kierownik Laboratorium Nafty i Gazu

w Zakładzie Geologii i Geochemii

Instytut Nafty i Gazu - Państwowy Instytut Badawczy ul. Lubicz $25 \mathrm{~A}$

31-503 Kraków

E-mail:irena.matyasik@inig.pl

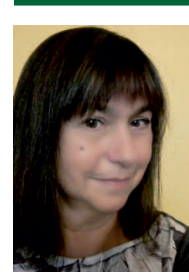

Mgr Maria KIERAT

Główny specjalista inżynieryjno-techniczny

w Zakładzie Geologii i Geochemii

Instytut Nafty i Gazu - Państwowy Instytut Badawczy ul. Lubicz $25 \mathrm{~A}$

31-503 Kraków

E-mail: maria.kierat@inig.p

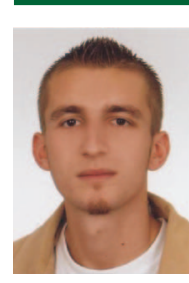

Mgr inż. Wojciech BIELEŃ

Starszy specjalista badawczo-techniczny w Zakładzie Geologii i Geochemii

Instytut Nafty i Gazu - Państwowy Instytut Badawczy

ul. Lubicz 25 A

31-503 Kraków

E-mail: wojciech.bielen@inig.pl
Sonoda T., Ona T., 2003. Rapid characterization of wood extractives in wood by thermal desorption-gas chromatography in the presence of tetramethylammonium acetate. Journal of Analytical and Applied Pyrolysis, 67: 191-200.

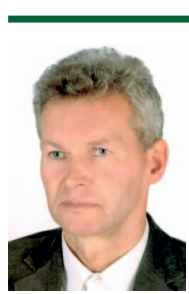

Mgr Marek ZAPAŁA

Starszy specjalista inżynieryjno-techniczny

w Zakładzie Geologii i Geochemii

Instytut Nafty i Gazu - Państwowy Instytut Badawczy

ul. Lubicz $25 \mathrm{~A}$

31-503 Kraków

E-mail: marek.zapala@inig.pl

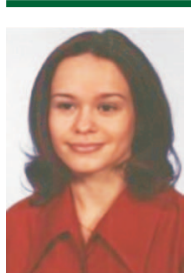

Mgr Małgorzata KANIA

Asystent w Zakładzie Geologii i Geochemii

Instytut Nafty i Gazu - Państwowy Instytut Badawczy

ul. Lubicz 25 A

31-503 Kraków

E-mail: malgorzata.kania@inig.pl

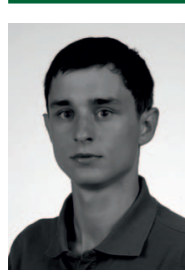

Mgr inż. Karol SPUNDA

Asystent w Zakładzie Geologii i Geochemii Instytut Nafty i Gazu - Państwowy Instytut Badawczy ul. Lubicz $25 \mathrm{~A}$

31-503 Kraków

E-mail: karol.spunda@inig.pl

\section{OFERTA BADAWCZA ZAKKADU GEOLOGII I GEOCHEMII}

petrofizyczne analizy laboratoryjne: gęstość, porowatość, parametry przestrzeni porowej, analizy przepuszczalności, analiza mikro i makro szczelinowatości na ptytkach cienkich i fragmentach rdzeni, petrograficzna ocena składu mineralnego, procesów diagenetycznych, analiza rozmieszczenia i geometrii przestrzeni porowej na podstawie ptytek cienkich, przepływy fazowe, zwilżalność, ściśliwość;

geochemiczne analizy laboratoryjne: ocena składu macerałowego i refleksyjności witrynitu, piroliza Rock-Eval (oznaczanie zawartości TOC, wolnych węglowodorów, węgla rezydualnego), określenie potencjatu węglowodorowego skat macierzystych, analiza elementarna węglowodorów i kerogenu (C,H,N,S, wspótczynniki H/C i O/C), skład chemiczny i izotopowy gazów, badania gazu wolnego (desorbowanego) i resztkowego, badania ekstrahowalnej substancji organicznej oraz analiza składu grupowego, analiza biomarkerów GC-MS (frakcja nasycona i aromatyczna, analiza GC-FID frakcji nasyconej), korelacja rop ze skatami macierzystymi;

modelowanie geologiczne 3D ztóż i obszarów poszukiwawczych: interpretacja danych geofizyki wiertniczej (petrofizyczna, geochemiczna, geomechaniczna, szczelinowatości), modelowanie strukturalne, facjalne i parametrów petrofizycznych z wykorzystaniem danych otworowych i sejsmicznych, modelowanie geomechaniczne, obliczanie zasobów na bazie modeli $3 D$ ztóż wraz z analizą niepewności;

sedymentologia dla geologii naftowej: analizy sedymentologiczne rdzeni wiertniczych, analizy środowisk depozycyjnych facji osadowych, stratygrafia sekwencji, analizy sedymentologiczne odstonięć powierzchniowych oraz ich integracja z danymi otworowymi (rdzenie, pomiary geofizyki otworowej) i sejsmicznymi, dystrybucja rozkładu facji w basenach sedymentacyjnych, predykcja występowania ciał zbiornikowych i ich orientacja przestrzenna w skali basenu sedymentacyjnego;

modelowanie 1D/2D/3D systemów naftowych: odtwarzanie ewolucji strukturalnej, termicznej i parametrycznej basenu sedymentacyjnego w skali czasu geologicznego, rekonstrukcja czasu i przebiegu procesów generowania i ekspulsji węglowodorów, modelowanie dróg migracji węglowodorów i miejsc ich akumulacji, ocena zasobów prognostycznych, analiza niepewności, ranking obiektów poszukiwawczych;

zintegrowana platforma: Petrel, PetroMod, Techlog, Interactive Petrophysics, ProGeo, Petrel Reservoir Geomechanics (Visage).

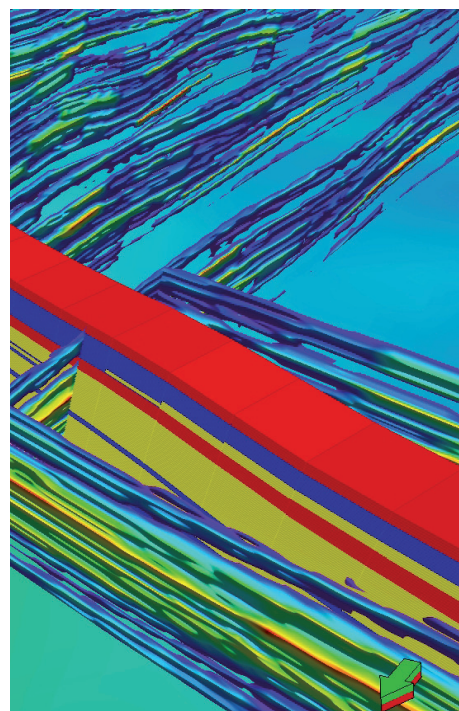

INSTYTUT NAFTY I GAZU

-Państwowy Instytut Badawczy 